\title{
Assessment of the diet and body composition of students recreationally training team sports
}

Authors' Contribution: A Study Design B Data Collection C Statistical Analysis D Data Interpretation E Manuscript Preparation F Literature Search G Funds Collection
Filip Michał Borys ${ }^{\mathrm{BDEF}}$, Beata Zyśk ${ }^{\mathrm{BCDE}}$, Adrianna Zańko ${ }^{\mathrm{BCD}}$, Dominika Chimkowska ${ }^{\text {BDE }}$, Joanna Smarkusz-Zarzecka ${ }^{\text {ABDE, }}$ Barbara Kiełczewska A, Lucyna Ostrowska ADE

Department of Dietetics and Clinical Nutrition, Medical University of Bialystok, Poland

\section{abstract}

Background: Knowledge about nutrition and supplementation during increased physical activity is still insufficient among people recreationally training sports. The aim of the study was to assess the diet, supplementation and nutritional status, as well as to characterize the body composition of students who recreationally train team sports.

Material and methods:

The study group consisted of 49 students from team sports sections (19 basketball, 10 volleyball and 20 football). The research tools used in the study were: a 24-hour nutritional interview, a questionnaire (concerning dietary supplementation, the frequency and duration of training) and the results of body composition analysis.

Results: The students' diets had insufficient energy value and deficiencies of EPA and DHA, carbohydrates, fiber and vitamin D. Excessive supply was related to: sodium, iron and vitamin C. 53\% of the respondents declared dietary supplementation. Noteworthy, students whose trainings were longer more often decided to change their eating behaviors.

Conclusions: The diet of the studied group was not properly balanced in terms of energy and some nutrients. The results of the assessment of students' diets indicate the necessity of nutritional education for people undertaking regular physical activity.

Key words: diet; supplementation; nutrients; physical activity; team sports; energy deficiency.

\section{article details}

Article statistics:

Full-text PDF:

Copyright Indexation:

Funding:

Conflict of interests: Corresponding author:

Open Access License:
Word count: 3,409; Tables: 2; Figures: 0; References: 22

Received: October 2020; Accepted: May 2021; Published: June 2021

http://www.balticsportscience.com

(c) Gdansk University of Physical Education and Sport, Poland

Celdes, Clarivate Analytics Emerging Sources Citation Index (ESCI), CNKI Scholar (China National Knowledge Infrastructure), CNPIEC, DOAJ, EBSCO - Central \& Eastern European Academic Source, EBSCO - SPORTDiscus, EBSCO Discovery Service, Google Scholar, Index Copernicus, J-Gate, Naviga (Softweco, Primo Central (ExLibris), ProQuest - Family Health, ProQuest - Health \& Medical Complete, ProQuest - Illustrata: Health Sciences, ProQuest Nursing \& Allied Health Source, Summon (Serials Solutions/ProQuest, TDOne (TDNet), Ulrich's Periodicals Directory/ ulrichsweb, WorldCat (OCLC)

This research received no specific grant from any funding agency in the public, commercial, or not-for-profit sectors. Authors have declared that no competing interest exists.

Joanna Smarkusz-Zarzecka Department of Dietetics and Clinical Nutrition, Medical University of Białystok, Mieszka I 4B Street, 15-054 Białystok; phone no.: (85) 73282 44; e-mail: joanna.smarkusz-zarzecka@umb.edu.pl

This is an open access article distributed under the terms of the Creative Commons Attribution-Non-Commercial-NoDerivatives 4.0 International (https://creativecommons.org/licenses/by-nc-nd/4.0/), which permits use, distribution and reproduction in any medium, provided the original work is properly cited, the use is non-commercial and is otherwise in compliance with the license. 


\section{INTRODUCTION}

Proper nutrition is very important among physically active people - not only in professional athletes, but also in people who exercise recreationally. A diet tailored to the player's needs and they specific sports discipline determines the proper functioning of the body, reduces the risk of injury, improves exercise capacity, and thus increases the chances of achieving better results. It is essential to select those food products and diversify athlete's menu that guarantee an adequate supply of energy and all other nutrients necessary for his health and training, such as: carbohydrates, proteins, fat, iron, calcium, magnesium, zinc, vitamin D, vitamin C, vitamin E, vitamin B and sodium [1, 2]. Energy and nutritional requirements depend on the type and intensity of physical activity, the duration of training sessions and the set goal (e.g. to increase muscle mass) and should be determined individually. Moreover, due to a large number of trainings in a microcycle, additional supplementation to increase the energy and nutritional value of the diet should be considered. The athlete should remember to properly hydrate the body, because any type of physical activity causes the loss of water from the body in the form of sweat, water vapor and urine. The nutritional plan should take into account not only the period of physical activity, but also the period before workout and the period of post-workout regeneration. Professional athletes are usually aware of the importance of nutrition in the training period; however, people training recreationally, especially enthusiasts of team sports, do not pay attention to shaping proper eating habits [2-5]. Among others, this is due to inadequate knowledge about nutrition with increased physical activity. It is well known that body composition largely depends on the diet and physical activity. Body composition assessment should be performed periodically and include an analysis of skeletal muscle mass, body fat mass, and body water content. The goal should be to achieve adequate body composition associated with optimal performance. In addition, players' body weight and height should be periodically checked. Increased body mass is unfavorable in team sports, such as football, volleyball and basketball, because it negatively affects players' speed and agility [2].

The aim of the study was to assess the diet and the nutritional status and to characterize the body composition in a group of students who recreationally train team sports: football, volleyball and basketball.

\section{MATERIAL AND METHODS}

Participants of this study were students belonging to sports sections of the Physical Education Department of the Medical University of Białystok in the 2018/2019 academic year. The respondents' mean age was $23.4 \pm 2.7$ years. The study involved 49 males -19 basketball, 20 football and 10 volleyball players. The participants recreationally trained those sports for 90 minutes twice a week. The place of the research was the Physical Education Department at the Medical University of Bialystok. The study was approved by the Bioethics Committee of the Medical University of Bialystok No.R-I-002/145/2018.

A 24-hour dietary interview was used to quantify the diet. The daily food intake was analyzed using the "Dieta 5" program. The losses of nutrients, vitamins and minerals during technological processing and storage of food products were taken into account. The energy and nutritional value of the participants' food rations were averaged. Then assessment of the energy supply and selected nutrients was compared to Nutrition Standards for the Polish Population [ 6]. Estimated Energy Requirement (EER) was established for healthy men aged 19-30, and the Physical Activity Level (PAL) was set at 1.6. The percentage of macronutrients, such as proteins (15\%), fats (30\%) and carbohydrates (55\%), was determined on the basis of the National Food and Nutrition Institute (Poland) [6] standards. The consumption of nutrients was compared to the Recommended Dietary Allowances (RDA) for: calcium, 
magnesium, iron, vitamin C, EPA and DHA. Other nutrients like: fiber, vitamin E, vitamin D and sodium were established based on the Adequate Intake (AI) [6]. The assessment of the supplementation was carried out using a proprietary questionnaire (single and multiple choice questions), which included also frequency and duration of workouts. Body composition was analyzed by bioelectrical impedance analysis (BIA) with a body analyzer (InBody 270, Korea).

All results were statistically analyzed using the STATISTICA 13.1 software by StatSoft. To check the relationship between the quality features, the Chi-square test of independence was used. The statistically significant results were considered at the level of $p<0.05$.

\section{RESULTS}

The participants' anthropometric parameters were assessed. Their mean age was $23.4 \pm 2.7$ years. The mean body weight was $83.7 \pm 9.2 \mathrm{~kg}$, and the mean height was $183.9 \pm 7.9$ $\mathrm{cm}$. The mean body mass index of the study group was $24.7 \pm 2.1 \mathrm{~kg} / \mathrm{m}^{2}$. Most important body components were also assessed. The means of the individual body components were as follows: fat $12.2 \pm 4.5 \mathrm{~kg}\left(14.6 \pm 5.3\right.$, visceral fat $\left.44.7 \pm 21.4 \mathrm{~cm}^{2}\right)$, skeletal muscle mass $40.9 \pm 5.7 \mathrm{~kg}$. The mean basal metabolic rate in the studied group was 1,902.6 $\pm 204.6 \mathrm{kcal}$. The results are presented in Table 1.

Table 1. Anthropometric data and parameters assessing the body composition of the group.

\begin{tabular}{lccc} 
& Mean \pm SD & Median & Min. - Max. \\
\hline Body height [cm] & $183.9 \pm 7.9$ & 182.0 & $167-203$ \\
Body mass [kg] & $83.7 \pm 9.2$ & 84.0 & $65.2-102.5$ \\
Body Mass Index (BMI) [kg/m²] & $24.7 \pm 2.1$ & 24.6 & $20.8-29.4$ \\
Body Fat Mass (BFM) [kg] & $12.2 \pm 4.5$ & 12.1 & $3-25.6$ \\
Percentage Body Fat (PBF) [\%] & $14.6 \pm 5.3$ & 15.0 & $3-30.2$ \\
Skeletal Muscle Mass (SMM) [kg] & $40.9 \pm 5.7$ & 41.2 & $29.6-56$ \\
Total Body Water (TBW) [kg] & $52.3 \pm 6.9$ & 52.4 & $38.6-69.8$ \\
Basal Metabolic Rate (BMR) [kcal] & $1,902.6 \pm 204.6$ & $1,901.0$ & $1,509.0-2,434.0$ \\
Visceral Adipose Tissue (VAT) [cm $\left.{ }^{2}\right]$ & $44.7 \pm 21.4$ & 40.0 & $10.0-110.0$ \\
\hline
\end{tabular}

The parameters related to the examined students' training were analyzed. 51\% $(n=25)$ of the respondents performed physical activity for an average of 60-90 minutes during one session, while $49 \%(\mathrm{n}=24)$ of the respondents trained for an average of above 90 minutes to 120 minutes. $63 \%(\mathrm{n}=31)$ of the players declared having one workout a week, while $37 \%(n=18)$ trained twice a week. $37 \%(n=18)$ of the respondents regularly undertook team sport trainings for $1-3$ months, while $63 \%(n=37)$ of them for 3-6 months. Most of the students $(90 \%, \mathrm{n}=44)$ undertook other forms of physical activity apart from scheduled training; $72 \%(\mathrm{n}=35)$ of them did it regularly and $18 \%(\mathrm{n}=9)$ occasionally. The rest of the students $(10 \%, \mathrm{n}=5)$ did not declare performing additional physical activity. The main reason for undertaking physical activity by the respondents $(43 \%, \mathrm{n}=21)$ was their interest in sport. Moreover, 29\% $(\mathrm{n}=14)$ claimed that they did it for health and fitness, and $27 \%(n=13)$ to improve their well-being. For $24 \%(n=12)$ of the students, sport was a form of relaxation, and for $12 \%(n=6)$ a way to reduce stress. Only $6 \%(n=3)$ of the athletes aimed to reduce body weight.

The daily diet, supply of energy and basic nutrients, as well as selected vitamins and minerals among the respondents was characterized. Results are presented in Table 2. The percentage share of proteins in covering the total energy value of the studied men was $20 \%$, fats $33 \%$ and carbohydrates $47 \%$. The study group meet the standards in 
consumption of fats, calcium and magnesium. However, an insufficient daily supply of energy, EPA and DHA, carbohydrates, dietary fiber and vitamin D was found in the daily food rations of the studied men. The consumption of proteins, sodium, iron, vitamin $C$ and vitamin $\mathrm{E}$ was too high (according to standards). There was also an incorrect ratio of plant and animal proteins.

Table 2. Consumption of nutrients in the performed group

\begin{tabular}{|c|c|c|c|c|}
\hline & Mean $\pm S D$ & Min. - Max. & Norm [6] & $\begin{array}{l}\text { Reference of the mean } \\
\text { value to the norms ( } \% \\
\text { of norm fulfillment) }\end{array}$ \\
\hline Energy [kcal]* & $2,503.72 \pm 814.05$ & $982.00-4,261.80$ & 2,900 & 86 \\
\hline Proteins [g] & $122.66 \pm 44.27$ & $37.71-230.51$ & 108.75 & 113 \\
\hline Animal proteins [g] & $85.43 \pm 37.72$ & $10.47-186.58$ & 54.38 & 157 \\
\hline Plant proteins [g] & $35.32 \pm 15.16$ & $14.06-72.18$ & 54.38 & 65 \\
\hline Fats $[\mathrm{g}]$ & $96.84 \pm 48.04$ & $16.62-234.81$ & 96.67 & 100 \\
\hline $\mathrm{EPA}+\mathrm{DHA}[\mathrm{mg}]^{* *}$ & $105.76 \pm 121.85$ & $0.00-465.50$ & 250 & 42 \\
\hline Carbohydrates [g] & $282.87 \pm 98.99$ & $92.75-492.97$ & 398.75 & 71 \\
\hline Fiber $[\mathrm{g}]^{* * *}$ & $21.96 \pm 8.96$ & $7.39-48.38$ & 25 & 88 \\
\hline Sodium[mg]*** & $3,996.51 \pm 2,171.68$ & $847.04-9,550.13$ & 1,500 & 266 \\
\hline Calcium [mg]** & $945.07 \pm 647.92$ & $130.76-2,915.20$ & 1,000 & 95 \\
\hline Magnesium [mg]** & $405.14 \pm 157.46$ & $142.26-852.90$ & 400 & 101 \\
\hline Iron [mg]** & $14.66 \pm 5.49$ & $4.67-28.54$ & 10 & 147 \\
\hline Vitamin D $[\mu \mathrm{g}]^{* * *}$ & $4.28 \pm 2.50$ & $0.70-12.65$ & 15 & 29 \\
\hline Vitamin $\mathrm{C}[\mathrm{mg}]^{* *}$ & $99.94 \pm 132.83$ & $7.00-683.15$ & 90 & 111 \\
\hline Vitamin E [mg]*** & $12.06 \pm 7.92$ & $3.43-38.22$ & 10 & 121 \\
\hline
\end{tabular}

Nutrition Standards for the Polish Population, amendment 2017. National Food and Nutrition Institute (Poland) [6]

* Estimated Energy Requirement [EER]

** recommended daily allowance [RDA]

*** adequate intake $[\mathrm{Al}]$

From among all the students $(\mathrm{n}=49), 38 \%(\mathrm{n}=19)$ of them declared changes in their diet due to taking up physical activity, $58 \%(n=28)$ of the respondents do not declared changes in their eating habits, and $4 \%(n=2)$ refused to answer. It was noticed that students whose trainings were longer more often decided to change their eating behaviors comparing to students whose duration of physical activity was shorter. These differences were statistically significant $(\mathrm{p}=0.04)$.

$53 \%(\mathrm{n}=26)$ students declared using dietary supplements. They usually chose protein and gainer supplements, branched chain amino acids (BCAA), omega- 3 acids, creatine, ginseng, guarana, lecithin, vitamin $\mathrm{D}$, magnesium, zinc and vitamin or mineral-vitamin preparations. Most of the students decided to take the supplements on their own, but some of them took into account the recommendations from trainers, dieticians and friends. Students who took the supplements learned about them from the Internet $(55 \%, n=27)$, friends $(22 \%, n=11)$, scientific literature $(18 \%, n=9)$, trainers $(16 \%, n=8)$ and from leaflets and sport literature $(8 \%, \mathrm{n}=4)$. Single athletes declared that they consulted a physician, pharmacist and dietician. The main goals of using supplements by students were replenishing missing nutrients $(38 \%, \mathrm{n}=10)$, preventing future shortages $(35 \%$, $n=9)$ and improving effectiveness of exercises $(27 \%, n=7) .85 \%(n=22)$ of the students declared taking supplements according to recommendations, and 15\% ( $\mathrm{n}=4)$ of them admitted to setting their own doses. $80 \%(n=21)$ of the respondents experienced beneficial effects of the supplements, and 15 of them noticed some positive changes after 2-4 weeks of use, 4 after 1-3 months, and 2 after a longer period of time. The rest of the respondents 
$(20 \%, \mathrm{n}=5)$ did not feel any difference after using supplements. $15 \%(\mathrm{n}=4)$ of the respondents experienced symptoms after taking the preparations. The symptoms included weakness, fatigue, chills, increased heart rate, rash, diarrhea and other gastrointestinal problems, as well as an allergic reaction.

\section{DISCUSSION}

Recreational team sports have a positive effect on physical and mental health [7]. In regular physical activity, the diet should be modified and adapted to the type of sport performed to prevent nutritional deficiencies, but a sharp increase in the supply of energy as well as macro and micronutrients can lead to excess weight gain.

In this study group, the mean height of the male body was $183.9 \pm 7.9 \mathrm{~cm}$, and the mean weight was $83.7 \pm 9.2 \mathrm{~kg}$. In a study by Devlin et al. on professional footballers, the players' mean body weight was $75.6 \pm 5.6 \mathrm{~kg}$, with a similar mean height of the athletes -180.4 $\pm 7.3 \mathrm{~cm}$ [8]. The mean weight of the adipose tissue in this study was $12.2 \pm 4.5 \mathrm{~kg}$, and in the group of professional football players $8.7 \pm 1.4 \mathrm{~kg}[8]$.

The mean energy value of the daily food rations of the studied group was too low comparing to standards [6] and amounted to $2,503.72 \pm 814.05 \mathrm{kcal}$ ( $86 \%$ of the norm). Too low supply of energy in relation to the demands was also observed in other studies. Defensive players (DP) of an American football team met the norm in $80 \%$, and the offensive players (OP) only in $69 \%$ [9]. The insufficient energy value of the diet also relates to people practicing as amateurs in various forms of physical activity [10]. Higher energy expenditure tied to the undertaken physical activity causes increased demand comparing to people who do not exercise. Insufficient caloric supply is common among people who train recreationally and may result from a fear of increasing the body weight [3-5].

In this study, the mean protein supply in the students' diet was $122.66 \pm 44.27 \mathrm{~g}(1.6 \mathrm{~g} / \mathrm{day} / \mathrm{kg})$ and covered $113 \%$ of the standard. Moreover, an incorrect ratio of animal and vegetable proteins was found. Animal protein met $157 \%$ of the norm, and plant protein - $65 \%$. Other studies also showed a higher supply of animal proteins than plant proteins and a relatively high total supply of all proteins. All American football players from team mentioned above ate too much proteins (OP $127.3 \pm 37.7 \mathrm{~g}$, DP $156.3 \pm 42.7 \mathrm{~g}$ ) [9]. Additionally, too high protein intake in recreational training participants was also found by Michnowska et al. [10]. A higher supply of protein can help compensate muscle damage and accelerate regeneration, and is especially desirable in the case of strength training [11]. However, in this studied group it is not necessary, because of a small number of trainings and their low intensity.

In this study, the mean fat supply was $96.84 \pm 48.04 \mathrm{~g}(1.1 \mathrm{~g} / \mathrm{kg}$ bw/day). The demand was covered in accordance with the applicable recommendations. Similar results were obtained by Smarkusz et al. in their studies, as well as by Michnowska et al., in which the competitors on average consumed $97 \mathrm{~g}$ and $99 \mathrm{~g}$ of fats per day [9, 10]. In the studied group, a strong deficiency of DHA and EPA was found: the consumption of these two polyunsaturated fatty acids met only $27 \%$ of norm. This could be due to the low consumption of fish by the entire Polish population [12]. Omega-3 fatty acids improve endurance [13] and have antiinflammatory properties [14]; therefore, their supply is essential when undertaking physical activity. However, some of the surveyed students declared supplementation with omega-3 acids, which is a good solution for demographic and economic reasons.

The mean supply of digestible carbohydrates in the respondents' diet was $282.87 \pm 98.99$ $(3.4 \mathrm{~g} / \mathrm{day} / \mathrm{kg})$ and was too low in relation to the recommendations ( $71 \%$ of the applicable 
standard). In previous studies conducted on an American football team [9], the amount of carbohydrates in the players' diets was higher than in this study, but still lower than assumed in the norms. American football players from the defensive formation on average consumed $373.8 \pm 117.2 \mathrm{~g}$, and from the offensive formation $317.8 \pm 123.3 \mathrm{~g}$ [9]. Michnowska et al. also noted a deficiency of carbohydrates in the diets of the study group [10]. As the International Society of Sports Nutrition suggests, people practicing endurance sports should focus on consuming the right amount of carbohydrates (6-10 g/day/kg) in order to achieve optimal performance [11]. In team games, high-intensity activities alternate with low-intensity activities (sprints and slow runs in football). This type of training leads to a depletion of muscle glycogen. Increasing carbohydrate stores in the liver and muscles before training helps delay the fatigue during long, intermittent, variable speed running [15].

The students supplied an average of $4.28 \pm 2.50 \mu \mathrm{g}$ of vitamin $\mathrm{D}$ in their diets and covered only $29 \%$ of the daily requirements. The main source of vitamin D is cutaneous synthesis under the influence of sunlight [16]. Vitamin D deficiencies are common in the Polish population. In the studies of Holick et al., the correct level of vitamin D was found only in $9.1 \%$ of the studied population [17]. For this reason, routine supplementation at a dose of 800-2,000 IU/day is recommended for adults from September to May. In the summer months, supplementation is recommended, but not necessary. However, in the case of diagnosed deficiencies, vitamin $\mathrm{D}$ supplementation should be used throughout the year in a dose depending on the size of the deficiency [18]. Vitamin D is important for athletes because it affects muscle strength, prevents injuries, and maintaining its proper level (30-50 ng / ml) can improve sports performance [19].

The daily dose of calcium in students' diet was on average $945.07 \pm 647.92 \mathrm{mg}$ and accounted for $95 \%$ of the demand. For comparison, the group of American football players in other studies [9] supplied an average of 1,043.1 $\pm 769.9 \mathrm{mg}(\mathrm{DP})$ and $847.5 \pm 547.3 \mathrm{mg}$ (OP) of this ingredient daily. Calcium is the main building block of bones, so the diet, mainly of young athletes, should be rich in this ingredient [20]. Additionally, calcium is excreted in sweat during sports together with sodium and other electrolytes [20]. Therefore, an adequate supply of both elements should be ensured.

The diets of students contained an average of 3,996.51 $\pm 2,171.68 \mathrm{mg}$ of sodium, which exceeded the norm by more than twice. Other researchers noted an even higher supply of sodium in the daily food rations of the participants [9]. Increasing the availability of salt (sodium chloride) in the diet can help maintain fluid balance and prevent dehydration in the heat or during intense training [21], while recreational exercise is not recommended for increasing sodium in the diet.

The supply of iron in the diet is important for the athletes' health and performance; unfortunately, the deficiency of this nutrient is a frequent phenomenon in endurance athletes [1]. This is because of high-intensity exercise followed by post-exercise hemolysis. However, in this study, the supply of iron in the students' diet exceeded the needs. They provided $14.66 \pm 5.49 \mathrm{mg}$ of this micronutrient and met the norm in $147 \%$. The reason for such a high supply may be the high consumption of meat - characteristic of the Podlasie voivodeship. Similar results were obtained by authors of other studies whose study group came from the same region [9].

In this study $53 \%$ of men used supplementation. Skop-Lewandowska et al. analyzed the intake of supplements and nutrients by persons attending fitness clubs: $47 \%$ of men supported their diets by using additional preparation [22]. In our research as many as $55 \%$ of respondents obtained knowledge about supplements from the Internet and $22 \%$ from 
friends, only $16 \%$ got their knowledge from a trainer, $18 \%$ from scientific literature, and the least number of people used the advice of a doctor, pharmacist or dietitian. Similarly, in the study by Skop-Lewandowska, the main source of knowledge about supplements were the mass media (45\%). In addition, $28 \%$ of men consulted a doctor, and $20 \%$ - a pharmacist. The friends' opinion was a source of knowledge only for $5 \%$ of the respondents [22]. In our research, 85\% students declared using supplements according to recommendations. In a study by Skop-Lewandowska et al. 65\% of the respondents followed the guidelines [22]. This study showed, that the most frequently chosen preparations by students were: protein and gainer supplements, branched chain amino acids (BCAA), omega-3 acids, creatine, ginseng, guarana, lecithin, vitamin $\mathrm{D}$, magnesium, zinc and vitamin or mineral-vitamin preparations. Other authors' studies also showed a frequent use of protein supplements [9]. Both professional and recreational athletes should remember that supplements are only an addition to the diet, not its substitute.

\section{CONCLUSIONS}

1. The mean energy value of the students' daily food rations was insufficient. Therefore, it is necessary to monitor the energy expenditure and energy supply not only of professional athletes, but also of people training recreationally.

2. The respondents' diets were not properly balanced. There were nutrient deficiencies in the diets, such as DHA and EPA, digestible carbohydrates, fiber and vitamin D. The excessive supply concerned: sodium, iron and vitamin C.

3. It was found that there is a relationship between increased physical activity and introducing beneficial modifications by the respondents in their diet.

4. Among the studied group, the use of sports supplements and other preparations was observed, despite recreational sports and moderate training intensity. It is important to control the supplement use as well as to monitor their effects on the male organism.

5. The diet of people with increased physical activity should be balanced in terms of energy and all diet components, as well as adapted to the type and intensity of physical activity. Nutritional education of people undertaking regular physical activity is very important.

\section{REFERENCES}

[1] Burke LM, Castell LM, Casa DJ, et al. International Association of Athletics Federations Consensus Statement 2019: Nutrition for Athletics. Int J Sport Nutr Exerc Metabol. 2019;29:73-84. https://doi.org/10.1123/ijsnem.2019-0065.

[2] Thomas DT, Erdman KA, Burke LM: Position of the Academy of Nutrition and Dietetics, Dietitians of Canada, and the American College of Sports Medicine: Nutrition and Athletic Performance. J Acad Nutr Diet. 2016;116:501-528.

[3] Shriver LH, Betts NM, Wollenberg G. Dietary Intakes and Eating Habits of College Athletes: Are Female College Athletes Following the Current Sports Nutrition Standards? J Am Coll Health. 2013;61:10-6. https://doi.org/10.10 80/07448481.2012.747526

[4] Kopeć A, Nowacka E, Klaja A, Leszczyńska T. Częstotliwość spożycia wybranych grup produktów spożywczych przez sportowców trenujących piłkę nożną [Frequency of consumption of selected groups of food products by athletes training football]. Probl Hig Epidemiol. 2013;94:151-157.Polish.

[5] Frączek B, Brzozowska E, Morawska M. Ocena zachowań żywieniowych zawodników trenujących gry zespołowe w świetle rekomendacji piramidy żywieniowej dla sportowców [Assessment of the nutritional behavior of players training team games according to the recommendations of the food pyramid for athletes]. Probl Hig Epidemiol. 2013;94:280-285.Polish.

[6] Jarosz M. Normy żywienia dla populacji Polski [Nutrition standards for the Polish population]. Instytut Żywności iŻywienia; 2017. Polish.

[7] Desbrow B, Slater G, Cox GR. Sports nutrition for the recreational athlete. Aust J Gen Pract. 2020;49:17-22. https:// doi.org/10.31128/AJGP-10-19-5108

[8] Devlin BL, Leveritt MD, Kingsley M, Belski R. Dietary intake, body composition, and nutrition knowledge of australian football and soccer players: implications for sports nutrition professionals in practice. Int J Sport Nutr Exerc Metabol. 2017;27:130-138. https://doi.org/10.1123/ijsnem.2016-0191

[9] Smarkusz J, Zapolska J, Witczak-Sawczuk K, Ostrowska L. Characteristics of a diet and supplementation of American Football Team players: Following a fashionable trend or a balanced diet? Rocz Państw Zakł Hig. 2019;70:49-57. https://doi.org/10.32394/rpzh.2019.0054 
[10] Michnowska I, Tomczak A. Ocena sposobu żywienia i wydatku energetycznego osób uprawiających rekreacyjnie różne formy aktywności fizycznej [Assessment of the diet and energy expenditure of people who engage in various forms of recreational physical activity]. Probl Hig Epidemiol. 2015;96:656-661. Polish.

[11] Jager R, Kerksick CM, Campbell BIet al. International Society of Sports Nutrition Position Stand: protein and exercise, J Int Soc Sports Nutr. 2017;14:20. https://doi.org/10.1186/s12970-017-0177-8

[12] Kołodziejczyk M. Spożycie ryb i przetworów rybnych w Polsce - analiza korzyści i zagrożeń [Consumption of fish and fish products in Poland - analysis of benefits and threats]. Rocz Państw Zakł Hig. 2007;58:287-293. Polish.

[13] Żebrowska A, Mizia-Stec K, Mizia M, Gąsior Z, Poprzęcki S. Omega-3 fatty acids supplementation improves endothelial function and maximal oxygen uptake in endurance-trained athletes, Eur J Sport Sci. 2015;15:305-314. https://doi. org/10.1080/17461391.2014.949310

[14] Calder PC, Albers R, Antoine JM et al. Inflammatory disease processes and interactions with nutrition. Br J Nutr. 2009;101:1-45. https://doi.org/10.1017/S0007114509377867

[15] Williams C, Rollo I. Carbohydrate nutrition and team sport performance. Sports Med. 2015;45:13-22. https://doi. org/10.1007/s40279-015-0399-3

[16] Płudowski P, Ducki C, Konstantynowicz J, Jaworski M. Vitamin D status in Poland. Pol Arch Med Wew. 2016;126: 530-539. https://doi.org/10.20452/pamw.3479

[17] Holick MF, Binkley NC, Bischoff-Ferrari A, et al. Evaluation, treatment, and prevention of vitamin D deficiency: An Endocrine Society Clinical Practice Guideline. J Clin Endocrinol Metabol. 2011;96:1911-1930. https://doi.org/10.1210/ jc.2011-0385

[18] Rusińska A, Płudowski P, Walczak M, et al. Zasady suplementacji i leczenia witaminą D - nowelizacja 2018 r. [Vitamin D supplementation guidelines for Poland - a 2018 update]. Post Neonatol. 2018;24. Polish. https://doi.org/10.31350/ postepyneonatologii/2018/1/PN2018001

[19] Abrams G, Feldman D, Safran M. Effects of Vitamin D on Skeletal Muscle and Athletic Performance. J Am Acad Orhtop Surg. 2018;26:278-285. https://doi.org/10.5435/JAAOS-D-16-00464

[20] Sale C, Elliott-Sale KJ. Nutrition and athlete bone health. Sports Med. 2019;49:139-151. https://doi.org/10.1007/ s40279-019-01161-2

[21] Kerksick CM, Wilborn CD, Roberts MD, et al. ISSN exercise \& sports nutrition review update: Research \& recommendations. J Int Soc Sports Nutr. 2018;15:38. https://doi.org/10.1186/s12970-018-0242-y

[22] Skop-Lewandowska A, Małek A, Gmur M, Kolarzyk E. Sposób żywienia oraz popularność stosowania suplementów diety i odżywek wśród młodych osób uczęszczających do klubów fitness [Diet and popularity of the use of dietary supplements among young people attending fitness clubs]. Probl Hig Epidemiol. 2013;94:786-793. Polish. 